\title{
Issue Voting and Government Responsiveness to Policy Preferences
}

\section{Eric Guntermann ${ }^{1} \cdot$ Mikael Persson $^{2}$ (D)}

Accepted: 22 April 2021

(c) The Author(s) 2021, corrected publication 2021

\begin{abstract}
Does citizens' voting behavior influence government policy? Conventional models of democratic representation assume that issue voting by citizens induces government responsiveness to citizens' preferences. However, existing research has not tested whether voting behavior makes any difference to responsiveness. We present a theoretical model of issue voting and policy responsiveness. We leverage Swedish election study panels and a corresponding dataset on policy implementation to empirically evaluate the influence of issue voting on the adoption by governments of popular policies. We find that parties that enter government are more likely to implement popular policies if supporters of a policy shift their votes towards those parties. Thus, issue voting can lead to government responsiveness as long as it does not force parties to be inconsistent with their prior positions.
\end{abstract}

Keywords Issue voting $\cdot$ Responsiveness $\cdot$ Policy preferences

Democratic theorists expect governments to represent citizens' policy preferences (e.g. Dahl, 1989) and elections provide the link between citizens' preferences and government policy (Powell, 2000). Beginning with Miller and Stokes (1963), numerous studies have assessed responsiveness of governments to citizens' preferences. However, only a small number of studies have considered whether voting by citizens influences policy responsiveness by government (Dassonneville et al., 2020; Griffin \& Newman, 2005).

We pursue this line of research by considering whether issue voting influences responsiveness. A prominent explanation for policy responsiveness is that citizens vote for parties that share their policy preferences and governments, in turn,

Mikael Persson

mikael.persson.3@gu.se

1 UC Berkeley, Berkeley, USA

2 The Gothenburg Research Group on Elections, Public Opinion and Political Behavior (GEPOP), Department of Political Science, University of Gothenburg, Gothenburg, Sweden 
represent those preferences, fearing that, if they fail to do so, citizens will punish them at the time of the next election (Downs, 1957; Manin et al., 1999).

While there is strong evidence that governments do what citizens want, to our knowledge, no published work has assessed the connection between issue voting by citizens and policy responsiveness by governments. As a result, it is currently unclear whether the way people vote has any influence on government parties' policy implementation decisions. We fill that gap.

The relationship between citizens' vote choice and government policy was most clearly formulated by Downs (1957). He argued that government parties adopt the level of government spending that allows them to win the most votes while avoiding losing votes. While Downs described policymaking as occurring along a single dimension, with governments selecting the amount of government spending that maximizes votes, actual policymaking is more complex for two reasons. First, policy positions cannot all be summarized by a single ideological dimension (e.g. Albright, 2010). Second, policy change is difficult because of the multiplicity of veto players (Tsebelis, 1995) as well as budget and time constraints, producing a status quo bias (Gilens, 2012).

Thus, when considering the relationship between popular preferences and government policy, we should focus on individual policies and we must consider that policymaking is costly. Therefore, governments compare the benefits they get from implementing a policy change, which, as explained below, include vote gains (or avoiding vote losses), to the costs of implementing them. The costs potentially include the costs of being inconsistent with voters' perceptions of government parties' positions (Downs, 1957).

The data necessary to assess the relationship between issue voting and policy responsiveness are available in Sweden. We use panel data from the Swedish National Election Studies (SNES) going back to 1960 to assess the extent to which issues influence vote choice. We then use an original dataset on policy implementation to determine whether issue voting increases the influence of issue opinions on government policy. We show that governments are more likely to implement popular policies when they gain votes from supporters of a policy change.

To our knowledge, this is the first study to bring together issue voting by citizens and policy responsiveness by governments. It is not hard to understand why scholars have failed to investigate this important topic. The data necessary to conduct such an investigation are considerable. First, distinguishing the influence of policy preferences on vote choice from the influence of party preferences on opinions requires panel data. Associations between policy preferences and vote choice in cross-sectional data may reflect either citizens changing their vote choice to reflect their policy preferences or vice versa (Lenz, 2012). Second, determining whether a policy position was implemented requires a massive dataset of the kind created by Gilens (2012) and Schakel (2019) for their work on inequalities in responsiveness. This is the first study to combine two such data sources.

The results suggest that representative democracy can work well. When citizens shift their vote choice in a way that gives government parties an incentive to represent citizens' preferences, governments act on their preferences. While far from an ideal of democracy in which governments care how citizens feel about issues and 
systematically adapt government policies to citizens' preferences, the image of representative democracy suggested by our study relies on citizens' interest in issues as well as parties' interest in re-election.

\section{Issue Voting and Responsiveness}

How do citizens get governments to do what they want them to do? One mechanism proposed in the literature is that elites follow citizens' preferences in order to win re-election (Miller and Stokes, 1963; Manin et al., 1999). This has been most clearly formulated in the spatial-modeling approach to politics. According to this view, parties adapt their policy programs and governments adapt their policies to citizens' preferences, in order to maximize their vote share (Downs, 1957). They do so because citizens are assumed to vote for a party that shares their policy preferences. Typically, scholars present such issue voting as occurring along a single leftright ideological dimension. Parties converge towards the median voter and governments adopt the right level of taxation and government spending to maximize their proximity to that representative voter (Downs, 1957, p. 57).

There is a long line of research that has been skeptical that issues actually influence vote choice. Early work found that vote choice is largely stable (Campbell et al., 1960; Lazarsfeld et al., 1968), that policy preferences are unstable (Converse, 1964), and that citizens know little about government policy and the stances taken by parties (Campbell et al., 1960). While many studies claim to find evidence that issues influence vote choice, it is far from clear that voters' positions on individual policy issues have any influence on their voting behavior (Campbell et al., 1960, pp. 185-187). As Brody and Page (1972) pointed out, merely finding that policy preferences coincide with vote choice does not mean that the former influence the latter. Such an association may in fact reflect "persuasion" effects, whereby citizens are persuaded by their preferred party to adopt its positions (p. 457).

Lenz (2012) tested whether policy preferences influence vote choice by using panel data in a large number of cases where prior studies, using cross-sectional data, had concluded that issue preferences influenced vote choice. He found evidence that issues mattered in only one case. In the others, instead of policy preferences influencing vote choice, he found that citizens adapted their policy preferences to their vote choice. This is related to the phenomenon of partisan motivated reasoning (Bolsen et al., 2014; Druckman et al., 2013; Leeper \& Slothuus, 2014), whereby partisans adapt their policy preferences to their party. However, it is different because what Lenz shows is that voters adapt their policy preferences to reflect the positions taken by the party they vote for.

While citizens often adopt the policy positions of the party they vote for, there is no reason to expect the direction of causality between issues and party preferences to always go from party to issues. The authors of The American Voter, in spite of their belief in the stabilizing influence of party identification, argued that voters can change their party if they hold a position that is inconsistent with their party's stance on an issue that matters to them (169). Recent studies have argued that citizens are motivated reasoners who reason to support their prior attitudes (Bolsen et al., 
2014; Druckman et al., 2013; Lodge \& Taber, 2013; Leeper \& Slothuus, 2014). However, even if citizens are biased reasoners, their issue attitudes may matter to their vote choice and there is no reason why the attitudes citizens seek to support should always be their party preferences. Mullinix (2016) shows that, when citizens are induced to consider an issue important to them, they are more likely to engage in motivated reasoning to support their policy preferences. Relatedly, Tesler (2015) showed that policy-relevant attitudes influence vote choice when they are crystallized. Thus, even if issues do not matter most of the time, this does not imply that they never matter.

The fact that citizens sometimes vote on the basis of issues may help account for one of the recurring findings in studies of policy responsiveness; the strong relationship between the public's policy preferences and government policy (Burstein, 2003). In the U.S., Monroe (1979) and Page and Shapiro (1983) found that, most of the time, when a majority of Americans favor a policy, the government implements that policy. Evidence from other countries suggests similar levels of policy responsiveness as in the US (e.g. Petry \& Mendelsohn, 2004). Moreover, Gilens (2012) and Schakel (2019) found that the probability of a policy's implementation increases monotonically with the proportion of the population that favors it, in the US and the Netherlands, respectively. Using a dynamic approach, Erikson et al. (2002) and Soroka and Wlezien (2010) found that government policy tracks public preferences over time. However, none of these studies directly consider whether issue voting influences responsiveness. The closest to assessing that link is the finding by Soroka and Wlezien (2010) that responsiveness by citizens to changes in government policy conditions government responsiveness to their preferences and the finding that policy responsiveness is higher on high-salience issues (Druckman \& Jacobs, 2006; Lax \& Phillips, 2009, 2012; Page \& Shapiro, 1983).

\section{A Model of Issue Voting and Policy Responsiveness}

Our model of policy responsiveness focuses on two actors: citizens and the government. Voters may derive positive, negative or zero utility from a particular policy proposal. The government is a collective actor composed of one or more parties, which, in turn, are made up of leaders, activists, and members. We assume that governments pursue policies and votes. They want to implement their preferred policies and they want to maximize their chances of re-election. ${ }^{1}$

Governments derive policy utility from each policy, which represents how much the party or parties in government will benefit or suffer from a policy itself. It can be positive, negative or zero. We represent the policy utility to a government of policy j by $P U_{j}$. The government also gets electoral utility from the policies it adopts. Electoral utility reflects the votes it gains or loses as a result of

\footnotetext{
1 Note that we conceive of governments as unitary actors. However, the conflicting preferences of parties in government and of the individuals who compose them are included in our model as implementation costs.
} 
adopting a policy. Electoral utility is likely 0 for most policies because citizens are unlikely to care about most issues.

However, government parties can gain votes (or at least avoid losing votes) from implementing a policy proposal if that change is popular and voters care enough about it to change their vote choice. They can also lose votes from implementing a policy proposal if it is unpopular and voters care enough about it to change their vote choice. They can also gain or lose votes from not implementing policies.

Electoral utility from implementing a policy change increases as public support for that change increases and as the potential vote losses from not implementing the policy change increase. The government's electoral utility is thus public support $\left(S_{j}\right)$ for a policy change weighted by its importance to citizens' voting decisions $\left(I V_{j}\right)$, in other words, how much issue voting occurs on an issue. The issue voting that should matter to electoral utility is recent issue voting. We thus focus on vote shifts during election campaigns that are motivated by policy preferences. We consider vote shifts to be motivated by policy preferences if supporters of a policy change their vote choice towards or away from parties that enter government during an election campaign more than policy opponents. Such short-term issue voting is relevant to electoral utility because it reflects voters' willingness to reward or punish government parties for policy implementation. Issue voting in the most recent election should be most important because it is the most recent signal of what voters care about. The electoral utility to the government is equal to:

$$
E U_{j}=S_{J} * I V_{j}
$$

The government's total utility from adopting a policy change $\left(T U_{j}\right)$ is thus the sum of their policy utility and their electoral utility.

$$
T U_{j}=P U_{j}+E U_{j}
$$

Adopting a new policy is not without its costs though. Government parties have to consider veto players both within government (different parties in government and actors with different preferences within a particular party) and across institutions (notably the legislature and the bureaucracy). They also have to consider fixed budget and time constraints. The cost of adopting a policy is the sum of all the effort, political capital, and government funds that have to be expended to get all these actors to allow the new policy to be implemented. These are implementation costs $\left(I C_{j}\right)$. Government parties also have to consider consistency costs. As Downs (1957) argued, citizens reward parties for being consistent over time (pp. 105-108). Lupu (2016) documented the costs to parties in Latin America when they adopted inconsistent positions. There are, therefore, costs to implementing policies that run contrary to the positions expressed by one or more government parties in the past. We label this the consistency cost from adopting policy $\mathrm{j}\left(C C_{j}\right)$. Note that, given low levels of political knowledge among voters (Carpini et al., 1996), party positions per se should matter less to consistency costs than perceptions of government party positions. Total costs are the sum of implementation and consistency costs. 


$$
T C_{j}=I C_{j}+C C_{j}
$$

We expect a policy proposal to be adopted if the total utility $\left(T U_{j}\right)$ the government derives from it outweighs total costs $\left(T C_{j}\right)$.

If electoral utility is close to 0 (public opinion is evenly divided on an issue or citizens simply do not care enough about it for it to influence their votes), governments may simply adopt a policy because of the benefits to them. In other words, they implement a policy change because their policy utility is greater than the cost of adopting the policy. Our focus is on electoral utility. In particular, we focus on the impact issue voting on a particular proposal has on electoral utility and, in turn, on whether that makes total utility great enough to outweigh the costs of policy change. Issue voting on a proposal increases electoral utility from popular policies and decreases electoral utility from unpopular policies. Therefore, issue voting on a popular policy should increase total utility from a policy relative to the costs of implementation and, eventually, should induce the government to implement the policy. Due to the status quo bias in policy implementation (Gilens, 2012), issue voting should not generally influence the nonadoption of unpopular proposals unless the government would otherwise derive a large amount of utility from the proposal (enough to outweigh both negative electoral utility and the costs of implementation). Thus, our key expectation is that issue voting increases the probability that popular policies are implemented.

The direction of movement in vote choice should make a considerable difference to whether issue voting induces governments to represent citizens' preferences. If supporters of a popular policy change perceive the parties that enter government as favoring a policy change and then shift their votes to those parties, the government should derive positive policy utility from the proposal and no consistency costs (because citizens perceive the government parties as supporting the policy) and, therefore, should be more likely to adopt the policy. We call this opposition-to-government issue voting.

Hypothesis 1: Issue voting increases the probability that popular policies are implemented if supporters of a policy change shift their vote choice towards government parties.

However, if the government parties are perceived as opposing a policy change and supporters of that policy move away from those parties, electoral utility is unlikely to influence policy adoption. We call this government-to-opposition issue voting. The increase in electoral utility due to issue voting would have to outweigh the consistency cost from adopting a policy that does not correspond to perceptions of the parties' positions. Even if a policy is popular and even if the government party (or parties) lose (s) support from supporters of that policy, adopting such a policy implies large consistency costs.

Hypothesis 2: Issue voting does not increase the probability that popular policies are implemented if supporters of a policy change shift their vote choice away from government parties. 


\section{Data and Methods}

We rely on election survey panel data from the SNES in combination with an original dataset on the implementation of policy proposals asked about in the surveys. We use all (pre- and post-election) panel studies from Swedish parliamentary elections from 1960 to $2010 .^{2}$ Coders determined whether the issue proposals asked about in the election studies were implemented during the mandate of the government formed following the election. Details about the coding of policy implementation are in Section 16 of the the Online Appendix. ${ }^{3}$

The dependent variable in all analyses of issue voting is a binary vote choice variable indicating a vote for the party (or one of the parties) that ended up in government after the election. We consider issue voting to occur when citizens with a given policy preference adjust their party choice to reflect that policy preference. Since other voters may move in the same direction, we consider issue voting to occur to the extent that changes in support for a party are greater among supporters of a policy change than among opponents. If those who support a policy proposal move their votes in a particular direction more than those who oppose the change, the difference between these changes can be seen as reflecting the effect of an issue on vote choice. ${ }^{4}$

Following Lenz (2012), we run linear probability models of vote choice and use panel data to assess issue voting. ${ }^{5}$ We run simpler models though in which we regress post-election vote choice on pre-election vote choice and the other righthand-side variables. In addition to being simpler than the models used by Lenz, they have the added advantage of controlling for regression to the mean (Finkel, 1995).

While policy preference questions were asked in different ways in different studies, we standardize the coding across issues and studies so that respondents who oppose a proposal are coded 0 and those who support it are coded 1, regardless of the strength of those positions. Respondents who assert that they neither support nor

\footnotetext{
${ }^{2}$ We exclude the 1970 study, which consisted of a single wave.

3 We exclude the 1956 study, because it did not include any question on overall policy orientations that could be used as a control. We do not include more recent election studies because data on policy implementation are not yet available. Twenty-eight of the SNES questions were about support for status quo policies. In these cases, we recoded them to be about changes away from the status quo. Results are similar when these issue proposals are removed from the dataset.

4 Prior studies of issue voting control for a predisposition allowing them to determine whether changes in vote choice are due to a particular policy and not simply to voters' general political orientations. Typically, scholars control for partisanship (Miller \& Shanks, 1996). However, the concept of party identification has been much more controversial in Europe than in the US (Holmberg 1994; Thomassen, 1976). The models reported in this paper, therefore, control for citizens' self-placements on the left-right ideological scale, which has conventionally been seen as a summary measure of citizens' policy preferences (e.g. Dalton, 2017). This control allows us to ensure that changes in vote choice are due to specific policy preferences and not to more general policy attitudes. In other models, we control for both ideology and party identification as robustness checks. We were able to run these models for a reduced set of elections (from 1968 to 2010) in which election studies asked about partisanship. Results are in the Online Appendix (Sect. 4).

5 We also run logistic regression models of vote choice. These can be found in Sect. 3 in the Online Appendix.
} 
oppose a change are coded 0.5 . Those who answer that they do not know or who refuse to answer were dropped. We adopted this coding scheme due to variations in response options across issues. There were two major variations across issue questions. Some included a neutral ambivalent category, while others did not and some issue questions assessed the intensity of support and opposition. We rescaled ideology from 0 to $1 .^{6}$

For each issue, we regressed post-election vote choice on pre-election vote choice, policy preferences, and pre-election ideological self-placement. Controlling for the lagged dependent variable, makes our issue voting model a model of change (Finkel, 1995). It is crucial to use a lagged dependent variable model of change rather than a model with change as the dependent variable because campaign surveys contain considerable random noise (Gelman \& King, 1993; Holbrook, 1994), thus making controlling for regression to the mean necessary. This is our model of issue voting:

$$
\text { Vote Choice }_{\text {post }}=\alpha+\beta_{1} * \text { Vote Choice }_{\text {pre }}+\beta_{2} * \text { Opinion }_{\text {pre }}+\beta_{3} * \text { Ideology }_{\text {pre }}+\epsilon
$$

We ran separate models for each issue, because it was not always clear whether some issue positions caused others. If preferences on one issue caused preferences on another, coefficients on the former in a model controlling for the latter would be biased. For the same reason and because the questions asked varied across surveys, we did not attempt to include all determinants of vote choice. The disadvantage of our necessarily underspecified models for each issue is that some of the significant relationships may be spurious (due to other attitudes). However, ending up with some false positives at the first stage simply makes the second stage regression, where we assess the impact of issue voting on policy responsiveness, more conservative.

We assess the level of issue voting by taking the coefficient on the pre-election opinion variable from each of these models. It represents the difference in the between-wave change in the probability of voting for a governing party between a respondent who opposes an issue proposal and one who supports it. We test the significance of the opinion coefficient for each issue using two-tailed t-tests. Given our focus on changes in vote choice, we rule out the possibility that voters' policy preferences reflect prior support for a government party.

We obtain three measures of issue voting. Total issue voting is simply a dummy indicating that the coefficient on the opinion variable is significant (and thus either positive or negative), opposition-to-government issue voting is assessed by a dummy indicating that the coefficient is significantly different from 0 and positive (significantly negative values are excluded from analyses using this variable), governmentto-opposition issue voting is measured by a dummy indicating that the coefficient is significant and negative (significant positive values are excluded). All these significance tests are based on two-tailed t-tests using a 0.05 significance level. Opposition-to-government issue voting implies that citizens perceived the government

\footnotetext{
${ }^{6}$ Respondents with missing values on ideology were given the median ideology score to avoid losing observations.
} 
parties as supporting the proposal, while government-to-opposition issue voting implies that citizens perceived the government parties as opposing the proposal. We distinguish these measures to test Hypothesis 2. Note that we also ran all secondstage analyses using analogous continuous measures of issue voting and results are similar. These are in Section 5 of the Online Appendix.

At the second stage, we assess the impact of issue voting on the link between public opinion and policy implementation. We create a binary variable indicating that a policy proposal was implemented during the term following an election (see Persson Forthcoming $b$ for a detailed description of this dataset). We then run a linear regression of that variable on the interaction between the percentage of survey respondents who support a policy change and the measure of issue voting. We also include an interaction with overall changes in the proportion supporting government parties between the pre- and post-election survey waves. This second variable allows us to ensure that the coefficients on our measures of issue voting are not merely picking up the impact of overall changes in votes during the campaigns as opposed to issue-specific changes (i.e. if governments are more responsive following more competitive campaigns). Equation 2 shows the model. Here we present results using linear models. Results using logistic regression models are similar and are in the Online Appendix (see Sect. 6).

$$
\begin{aligned}
\text { Policy Implemented }= & \alpha+\beta_{1} * \text { Public Support }+\beta_{2} * \text { Issue Voting }+\beta_{3} * \text { Total Changes } \\
& +\beta_{4} * \text { Issue Voting } * \text { Public Support }(\%) \\
& +\beta_{5} * \text { Total Changes } * \text { Public Support }(\%)+\epsilon
\end{aligned}
$$

We include all issues that were asked about in the pre-election studies. We limit first-stage analyses to respondents who participated in both the pre- and post-election studies, for whom we can assess changes in vote choice. In total, we have 202 observations on 81 unique issue proposals. Table A1 in the Online Appendix lists all the issues we have included as well as the years of the elections in which the preelection studies asked about them. Note that our measures of public support include non-responses so that they show the proportion of all Swedes who want a policy change.

\section{How Much Issue Voting Occurred?}

Figure 1a shows the absolute amount of issue voting (the absolute value of the coefficient on the opinion variable from the first stage) on each issue that has been asked about in the SNES going back to 1960. It labels the five issues with the greatest amount of issue voting. These issues are politically-heated issues that were salient at the time. A good example is the issue of whether to introduce wage-earner funds, which was a proposal by the Social Democrats to gradually introduce collective employee ownership of private companies. Figure $1 \mathrm{~b}$ shows the relationship between the percentage-point change in votes associated with each issue (i.e. the raw coefficient on the opinion variable) and public support 

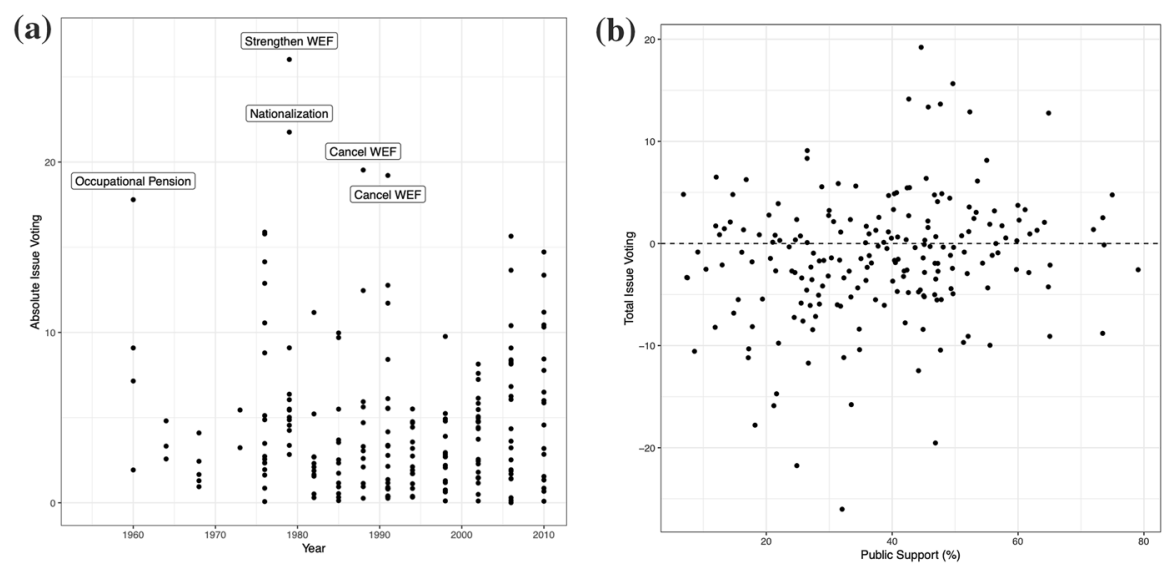

Fig. 1 Amount of issue voting. a Absolute issue voting over time. b Public support and issue voting

for it. The correlation between the two is $0.19(\mathrm{p}=0.01)$. There is thus a weak tendency for there to be a greater shift in votes towards government parties due to issue proposals when more citizens support a policy change.

Table 1 shows descriptive statistics on the amount of issue voting as assessed using the linear model. For each type of issue voting, we present the percentage of issues with significant issue voting as well as the minimum, median, maximum, and mean values of significant values.

While most issues do not influence vote choice, we estimate that over a third do matter to voters. Support for proposals is associated with losses of support by government parties about twice as often as it is associated with gains by them. This does not mean that issues overall hurt government parties, because, as we saw above, there is a positive (albeit weak) association between support for policy proposals and the estimated change in votes that is due to an issue.

Table 1 Amount of issue voting

\begin{tabular}{llllll}
\hline Type & $\% \mathrm{p}<0.05$ & Min & Median & Max & Mean \\
\hline Total & 37.1 & 3.54 & 7.60 & 26.02 & 8.81 \\
Opposition-to-Government & 11.9 & 4.10 & 5.99 & 19.21 & 8.35 \\
Government-to-Opposition & 25.2 & 3.54 & 8.14 & 26.02 & 9.02 \\
\hline
\end{tabular}




\section{Does Issue Voting Influence Government Responsiveness to Preferences?}

We first describe the relationship between public support for the policy proposals we consider and their implementation. Figure 2 shows the relationship between the percentage of the Swedish population that wants a new policy to be implemented and the implementation of each policy. We calculate the percentage of policies that are implemented in various ranges of ten percentage points of public support. We also include a rug plot to show the distribution of public support for policies. As we can see, the probability of implementation jumps dramatically when public support increases from low (i.e. below 30\%) to moderate (at and above 30\%) values. Above $30 \%$ support, however, the probability of implementation does not increase as support goes up. ${ }^{7}$

Does issue voting make a difference to policy responsiveness? We begin with a simple test. We compare the proportion of policies with majority (i.e. $50 \%+1$ ) support that were adopted in the presence of each type of issue voting and the proportion that were adopted when there was no issue voting. ${ }^{8}$ When there was no issue voting of any kind, $19 \%$ of popular policy proposals were implemented. When there was evidence of issue voting, $44 \%$ of popular proposals were implemented. Seventyfive percent of proposals with majority support were implemented when there was opposition-to-government issue voting. However, as expected, government-to-opposition issue voting essentially made no difference to policy implementation. When there was that form of issue voting, only $20 \%$ of popular policies were adopted. This lack of influence of government-to-opposition issue voting is consistent with our expectations. Government parties have an interest in remaining consistent with the positions that voters at least perceive them as having.

Figure $3 \mathrm{a}$ shows the relationship between public support for policy changes and their implementation by the type of issue voting. It calculates the percentage of policies that are implemented in 20 percentage-point intervals of public support. We can see that the percentage of implemented policies increases with public support on issues with significant opposition-to-government (Opp-to-Govt) issue voting (note that there was no significant opposition-to-government issue voting on proposals with public support below 20\%). When government-to-opposition (Govt-to-Opp) issue voting is significant, on the other hand, implementation only increases with public support when it goes above $60 \%$.

Figure $3 b$ shows the same data points as in Fig. 1b. However, it now shows whether policy proposals were implemented or not. It also shows a vertical dashed line at $50 \%$ public support to distinguish policies with majority support from those lacking such support. It also includes a horizontal dashed line at 0 issue voting (in

\footnotetext{
7 We produced analogous graphs for a broader sample of issues including those asked about in SOM (Society Opinion Media) surveys in addition to the Swedish Election Studies. The patterns are very similar. See Online Appendix, Sect. 2.

${ }^{8}$ Note that the $50 \%$ threshold is somewhat arbitrary. Using other thresholds for high support leads to similar results.
} 


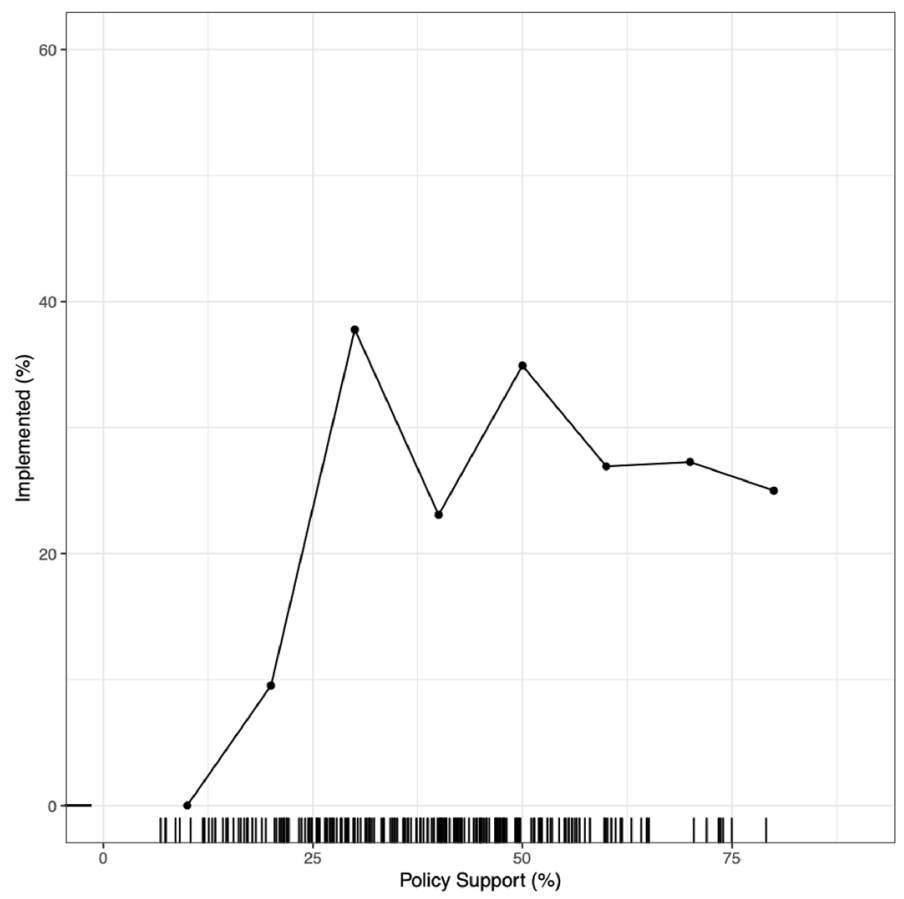

Fig. 2 Public support for policy proposals and their implementation

black), allowing us to distinguish opposition-to-government from government-toopposition issue voting. It, furthermore, includes lighter dashed lines at -1 and 1 issue voting, allowing us to identify issues with at least that much issue voting. We can see clearly that none of the popular policies that were implemented led to changes in support for government parties of less than one point in absolute value. Moreover, while eight popular proposals that were implemented had opposition-togovernment issue voting, only two proposals with majority support that were implemented had government-to-opposition issue voting. Implementation of popular proposals was thus clearly associated with issue voting and particularly with policy supporters shifting towards government parties.

We then adopted a more rigorous test. We ran linear regressions of the binary policy implementation variable on public support for the policy change, the measures of issue voting, the total change in vote shares for the government party (or parties), and interaction terms between public support and each of the latter two variables. Table 2 shows the results. The coefficients of interest are those on the interactions between each form of issue voting and public support. The results from Model 1 show that the coefficient on the interaction between total issue voting and the proportion of public support is positive. However, it is far from conventional significance levels. Model 2 shows that opposition-to-government issue voting significantly increases the weight of public opinion on policy adoption. In 
(a)

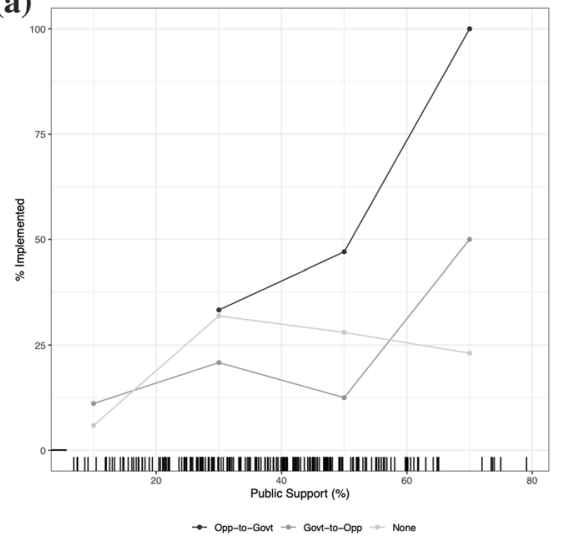

(b)

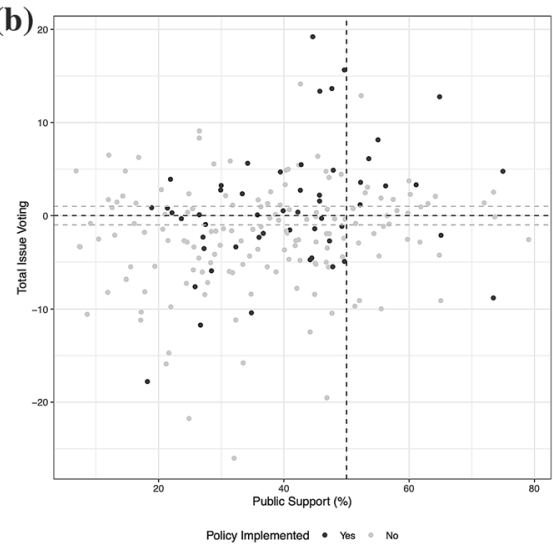

Fig. 3 Issue voting, public support, and policy implementation. a Percent Implemented. b Raw data points

the third column, we can see that government-to-opposition issue voting clearly has no effect on the influence of public opinion on policy change. These findings provide initial support for Hypothesis 1, that issue voting increases the likelihood that popular policies are implemented if supporters of a policy change shift their vote choice towards government parties. It also provides support for Hypothesis 2, that issue voting does not change the likelihood that popular policies are implemented if supporters of a change move their vote choice away from government parties.

We now more directly test the expectation that opposition-to-government issue voting increases the probability that the government implements popular policies while government-to-opposition issue voting does not. We consider the marginal effects of each form of issue voting at various levels of public support for policy changes. ${ }^{9}$ If issue voting improves policy responsiveness, we should find that, at high levels of public support for a policy, issue voting increases the probability of policy adoption. Confidence intervals on the marginal effect of issue voting should thus only cover positive values at high levels of public support. As we can see in panel (a) of Fig. 4, total issue voting does not significantly influence the probability of implementation at any level of public support. Opposition-to-government issue voting, as shown in panel (b), has an effect on policy implementation that is significant for levels of support of $50 \%$ and higher. Government-to-opposition issue voting, as panel (c) shows, has no effect on policy responsiveness. These marginal effects provide support for Hypotheses 1 and 2.

As an illustration, Table 3 shows an example of an issue that has been asked about repeatedly in Swedish election studies: lowering taxes. Three of the six times Swedes were asked about the issue, majorities supported tax cuts. In all but one

\footnotetext{
9 Note that these marginal effects plots, like all others we report, include rug plots of the distribution of support for policy changes.
} 
Table 2 Models of policy implementation

\begin{tabular}{|c|c|c|c|}
\hline & Model 1 & Model 2 & Model 3 \\
\hline Intercept & $\begin{array}{l}0.35^{*} \\
(0.16)\end{array}$ & $\begin{array}{l}0.29 \\
(0.18)\end{array}$ & $\begin{array}{l}0.33^{*} \\
(0.16)\end{array}$ \\
\hline Public Support (\%) & $\begin{array}{l}-0.00 \\
(0.00)\end{array}$ & $\begin{array}{l}-0.00 \\
(0.00)\end{array}$ & $\begin{array}{l}-0.00 \\
(0.00)\end{array}$ \\
\hline Total IV & $\begin{array}{l}-0.23 \\
(0.18)\end{array}$ & & \\
\hline Opp-to-Gov IV & & $\begin{array}{l}-0.75 \\
(0.47)\end{array}$ & \\
\hline Gov-to-Opp IV & & & $\begin{array}{l}-0.10 \\
(0.19)\end{array}$ \\
\hline Total Changes & $\begin{array}{l}-2.20 \\
(2.06)\end{array}$ & $\begin{array}{l}-1.04 \\
(2.44)\end{array}$ & $\begin{array}{l}-1.73 \\
(2.03)\end{array}$ \\
\hline Total IV*Public Support (\%) & $\begin{array}{l}0.01 \\
(0.00)\end{array}$ & & \\
\hline Opp-to-Gov IV*Public Support (\%) & & $\begin{array}{l}0.02^{*} \\
(0.01)\end{array}$ & \\
\hline Gov-to-Opp IV*Public Support (\%) & & & $\begin{array}{l}0.00 \\
(0.01)\end{array}$ \\
\hline Total Changes*Public Support (\%) & $\begin{array}{l}0.06 \\
(0.05)\end{array}$ & $\begin{array}{l}0.02 \\
(0.05)\end{array}$ & $\begin{array}{l}0.04 \\
(0.05)\end{array}$ \\
\hline$N$ & 202 & 151 & 178 \\
\hline$R^{2}$ & 0.04 & 0.06 & 0.01 \\
\hline $\operatorname{adj} . R^{2}$ & 0.01 & 0.03 & -0.01 \\
\hline Resid. sd & 0.44 & 0.45 & 0.43 \\
\hline
\end{tabular}

Standard errors in parentheses, $*$ indicates significance at $p<0.05$

case, over $45 \%$ of Swedes wanted a tax cut. Here, we lower the somewhat arbitrary threshold for high support to $45 \%$ to reflect actual support for a tax cut in Sweden. In the two cases in which there was opposition-to-government issue voting and strong support for a tax cut, taxes were reduced. In only one case (2002) out of three without opposition-to-government issue voting and with high support for tax cuts were taxes actually lowered. Thus, although Swedes almost always wanted a tax cut, they were much more likely to get a tax cut when they voted in a way that gave the parties in government an incentive to actually cut their taxes. 


\section{Are Government Parties Just Representing Their Supporters?}

One possibility is that parties in government are not responding to issue voting but instead are representing the preferences of their supporters. To test this possibility, we repeated our analysis of the impact of opposition-to-government issue voting on responsiveness to the preferences of supporters of parties that made it into government.

Figure 5 shows the marginal effects of issue voting at various levels of support for policy change among government-party voters (coefficients are in Sect. 8 of the Online Appendix). The rug plots show the distribution of support for policy changes among government-party supporters. We can see evidence that total issue voting and opposition-to-government issue voting mattered to policy responsiveness even among government-party supporters. The marginal effect of both types of issue voting is significant when $60 \%$ or more of government supporters favor a change. It is not surprising that issue voting matters among government-party supporters at a higher level of support for a policy change than among the rest of voters, because government-party supporters support popular policies their governments adopt more than voters overall (see distributions in Sect. 9 of the Online Appendix). Thus, governing parties do not always represent their supporters' preferences. They do so when their voting behavior gives them an incentive to implement their preferred policies. $^{10}$

\section{Considering Other Possible Explanations}

An important alternative explanation to consider is that issue voting matters for representation but only because it allows citizens to get governments that represent their preferences. Rather than governing parties caring about implementing policies that won them votes in the previous election, they may simply implement popular policies because governments supporting popular positions replace governments with unpopular positions. This is the electoral turnover (Stimson et al., 1995) or mandate (Manin et al., 1999) mechanism of policy responsiveness, discussed in the literature.

Government turnover is clearly associated with the implementation of popular policies. While a mere $4 \%$ of policies with majority support were implemented by re-elected incumbents, half of the popular policies were implemented by new governments. However, that does not mean that issue voting is any less important. When a new government was formed, $75 \%$ of popular policies with significant opposition-to-government issue voting were implemented. Conversely, under a new government, only $42 \%$ of issue proposals with majority support but no oppositionto-government issue voting were implemented. Opposition-to-government issue voting nearly doubles the proportion of popular policies that are implemented. There was no evidence of that type of issue voting on proposals with majority support

\footnotetext{
10 The measures of support for government parties used here are from the pre-election surveys. We ran similar models with support for policy change among government-party supporters from the post-election studies and results are similar (see Sect. 10 of Online Appendix).
} 
when the incumbent returned to power, suggesting that government turnover occurs when parties or a coalition of parties campaign on popular issues and gain support as a result. ${ }^{11}$ There is some weak evidence though that issue voting matters to policy responsiveness even in the absence of government turnover. If we consider issues with support above $45 \%$, we find evidence that opposition-to-government issue voting matters. $25 \%$ of such issue proposals were implemented when there was significant opposition-to-government issue voting, compared to $13.8 \%$ when there was no such significant issue voting. This evidence is weaker, but it does suggest that it, nonetheless, makes a difference.

Another alternative explanation is that what matters for responsiveness is not the existence of issue voting but instead the intensity of preferences. Issue voting may be more common when citizens have more strongly-held preferences and governments may care more about public opinion when preferences are more strongly held. For most of the issues for which we have data, the questions that were asked allowed citizens to express their degree of support or opposition to a policy change. Thus, to rule out this possibility, we create an aggregate measure of the intensity of preferences for each issue and include it as a control variable in models of policy implementation. We calculated the mean absolute value of the intensity of preferences across all respondents. Higher values thus indicate a stronger intensity of preferences on average. We then re-run the model of policy implementation testing the conditioning effect of opposition-to-government issue voting on the influence of public opinion on policy. However, we add the measure of preference intensity as well as an interaction between that variable and the public support variable. The first panel of Fig. 6 shows marginal effects of opposition-to-government issue voting at various levels of public support for policy changes. We can see that marginal effects are similar to those in Fig. 4b, which shows analogous effects without controlling for intensity. The second panel shows the marginal effects of preference intensity on the implementation of policy proposals. As we can see, preference intensity actually has a negative marginal effect on implementation controlling for opposition-to-government issue voting at most levels of public support. Thus, the increasing responsiveness to public opinion that results from opposition-to-government issue voting is not due to a greater intensity of preferences.

Before concluding, we should address some final concerns. We have focused on the impact of policy preferences and issue voting during election campaigns on policy implementation at any point during a government's term. However, policy preferences may change over time and the issues motivating party preferences may change. Parties should, therefore, consider issue voting and policy preferences less

\footnotetext{
11 Section 11 of the Online Appendix shows the scatter-plots of public support and issue voting for incumbent and non-incumbent governments. They show that, while new governments are more likely to gain support among supporters of a popular policy position, incumbent governments are more likely to lose support among supporters of unpopular policies. Government turnover thus appears to occur when a non-incumbent identifies a popular policy that matters to voters.
} 
as time goes by and we would expect issue voting to matter most early in government's terms. Hence, we consider the implementation of policies in each year following an election in Sect. 12 of the Online Appendix. We find that most of the impact of issue voting occurs during the first two years following an election. ${ }^{12}$

One possible explanation for our results is that governments care more about the preferences of the richest citizens and that the rich vote more on the basis of issues, thus producing our findings. We address this possibility by re-running our analyses but replacing overall preferences by the preferences of citizens at the 90th income percentile, which studies of responsiveness find have disproportionate influence on government policy (Gilens, 2012; Schakel, 2019, Forthcoming $a$ ). We find that issue voting conditions responsiveness to high-income citizens as well. Thus, our findings and those of Gilens (2012) and Schakel (2019) are complementary.

Finally, readers may be curious how much our findings can be generalized to other contexts. Sweden is particular for several reasons. Two important distinctions relate to its governments. Social Democratic governments have governed most of the time since universal suffrage was introduced. The Social Democrats governed following 10 of the 15 elections covered by this paper. Moreover, Sweden has had an abundance of minority governments (including 11 of the 15 governments covered by this paper). We control for these particularities of Swedish governments by adding them to regression models similar to those presented above. The results, presented in Sects. 14 and 15 of the Online Appendix, show that our findings hold up even with these controls.

\section{Conclusion}

While scholars widely assume that citizens' voting behavior gives governments an incentive to represent their preferences, they have yet to test whether there is a relationship between issue voting and policy responsiveness. We develop a model of issue voting and responsiveness in which a shift by supporters of a popular policy towards one or more parties that enter government increases government parties' electoral utility from a policy. In turn, this increases the likelihood that that policy change will be implemented.

Crucial to our model is the consideration of individual issues rather than a single ideological dimension as well as the consideration of the costs of policy change. Policies cannot all be summarized by a single policy dimension. Moreover, governments do not systematically represent citizens' preferences, because doing so is costly. They represent their preferences when the electoral benefits from doing so are sufficiently high that they outweigh the costs.

We found that citizens vote on the basis of many, but not all, issues that scholars have identified as important during election campaigns. Moreover, issue voting

\footnotetext{
12 We also show that our results are not due to disproportionate influence by particular issues in Sect. 13 of the Online Appendix.
} 
(a) Total Issue Voting

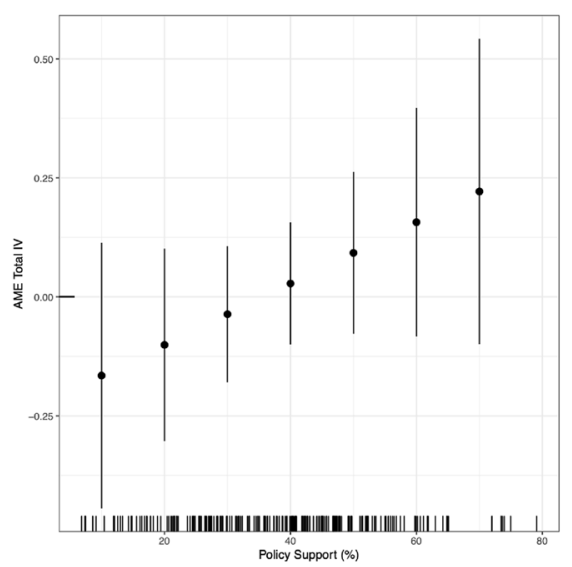

(b) Opposition-to-Government

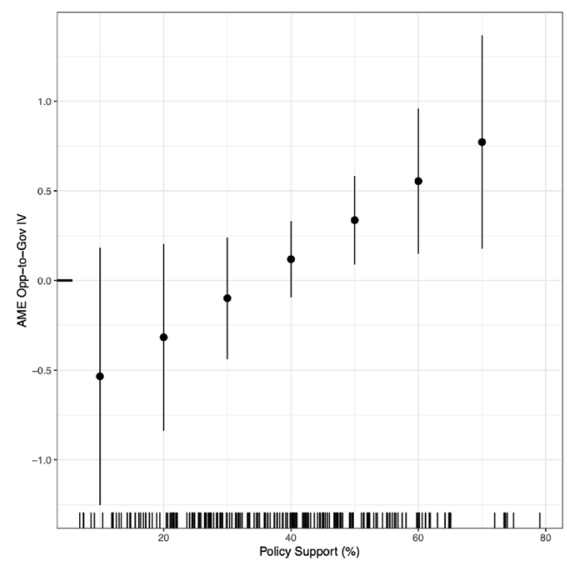

(c) Government-to-Opposition

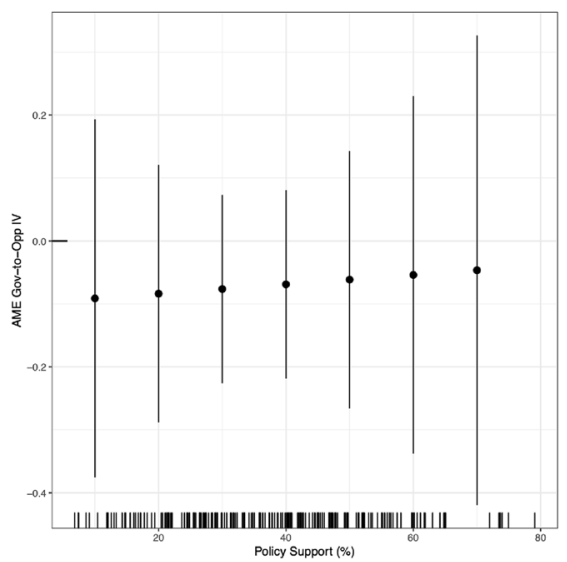

Fig. 4 Types of issue voting and the probability of policy implementation

influences policy responsiveness. When citizens who support a policy shift their vote choice towards parties that end up in government, those parties take notice and are more likely to implement popular policies than when citizens do not engage in that form of issue voting. These findings show that it is not enough for the public simply to support a policy change for that change to be implemented. Enough people have to consider an issue sufficiently important to shift their votes towards governing parties. Our findings thus support the conventional perspective on representation 
Table 3 Issue voting and tax cuts

\begin{tabular}{llll}
\hline Year & $\begin{array}{l}\text { Support for Tax } \\
\text { Cut }(\%)\end{array}$ & Opp-to-Govt IV & Tax Cut? \\
\hline 1964 & 79.08 & No & No \\
1968 & 36.32 & No & No \\
1998 & 61.72 & No & No \\
2002 & 49.26 & No & Yes \\
2006 & 55.02 & Yes & Yes \\
2010 & 45.73 & Yes & Yes \\
\hline
\end{tabular}

according to which government parties implement citizens' preferences in order to be re-elected. However, it modifies that model by showing that citizens only provide governments an incentive to represent them on certain issues. Thus, even government parties seeking re-election are not entirely constrained by public opinion.

There are two crucial limitations to our study. Like all studies of policy responsiveness, we are dependent on the set of issues surveys ask about. Thus, we may miss some issues that are important to voters. While this is a real problem for analyses of responsiveness, we believe this problem is reduced in our study because we use surveys from the Swedish National Election Studies (SNES), which are run by the top experts in public opinion and voting behavior in Sweden. Another limitation is that we cannot rule out the possibility that parties induce issue voting and in turn their own apparent responsiveness by making certain issues salient before the election. However, in a competitive political environment, no party has a monopoly on the salience of issues. Thus, issue voting cannot be entirely endogenous to party strategies.

Nevertheless, we believe there are grounds for optimism about the functioning of democracy. What should give governments the greatest incentive to represent people's preferences, changes in electoral behavior resulting from issue preferences, conditions responsiveness. In short, contrary to the subtitle of the recent book by Achen and Bartels (2016), elections do "produce responsive government." 
(a) Total Issue Voting

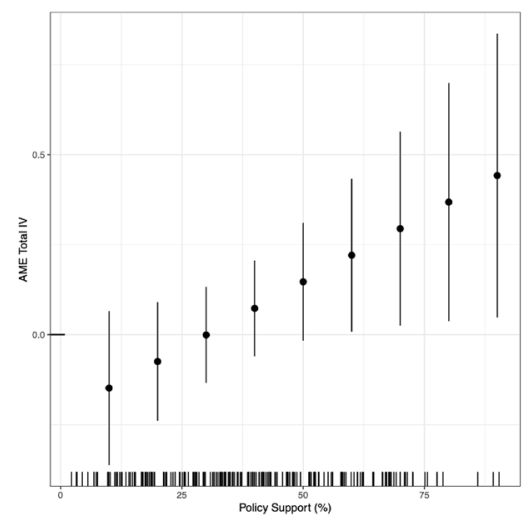

(b) Opposition-to-Government Issue Voting

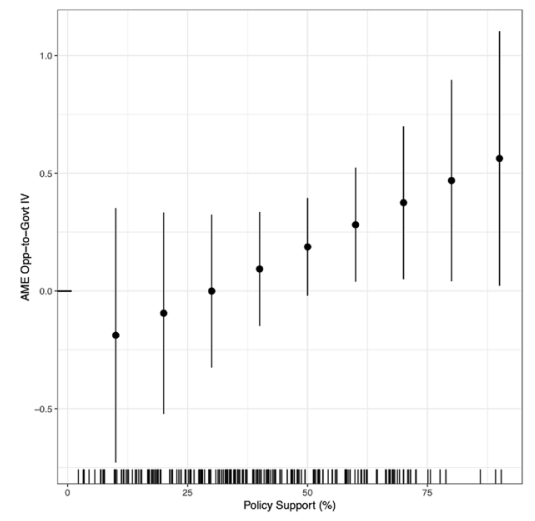

(c) Government-to Opposition Issue Voting

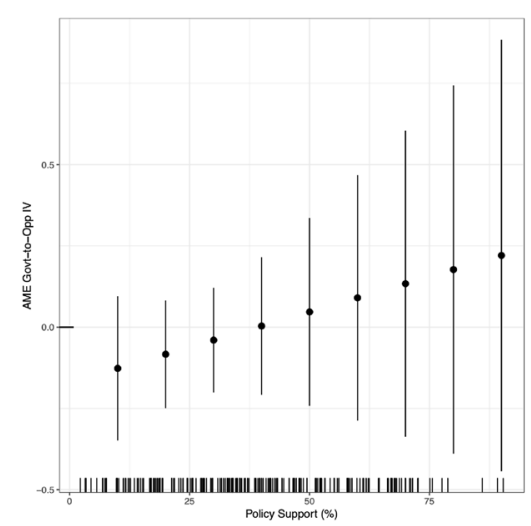

Fig. 5 Types of issue voting and responsiveness to the preferences of government party supporters 
(a) Opposition-to-Government Issue Voting

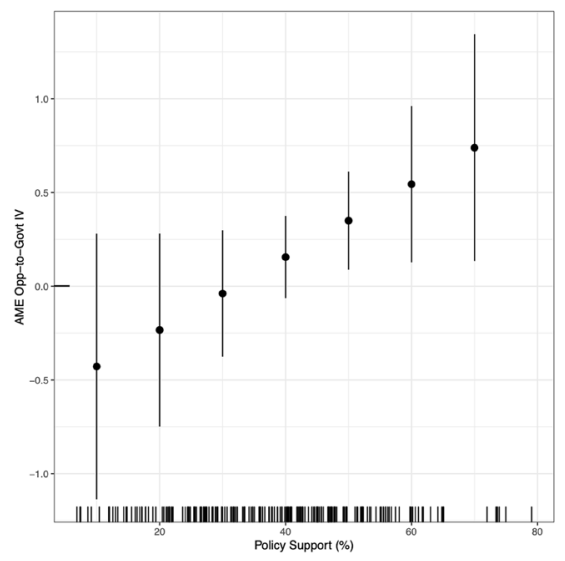

(b) Intensity

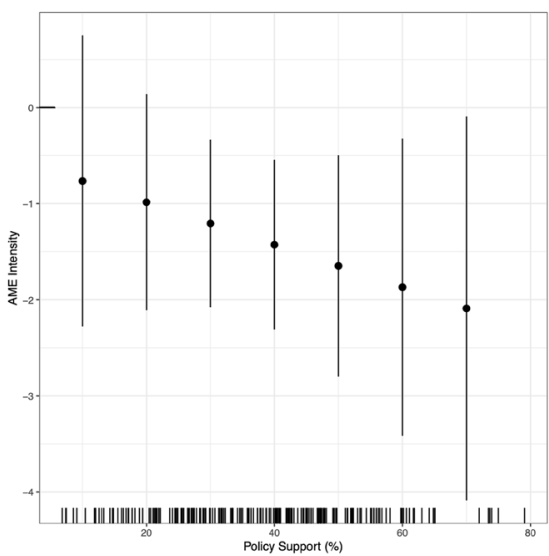

Fig. 6 Model of policy implementation including preference intensity

Supplementary Information The online version supplementary material available at https://doi.org/10. 1007/s11109-021-09716-8.

Acknowledgements The authors would like to thank Edana Beauvais, Royce A. Carroll, Mikael Gilljam, Romain Lachat, Gabriel Lenz, Zeynep Somer-Topcu, Mary Stegmaier, Chris Wlezien, Chris Wratil, and participants at 2017 Midwest Political Science Association Annual Conference, the 2017 European Political Science Association Annual Conference, the 2018 American Political Science Association Annual Meeting and the 2018 Toronto Political Behaviour Workshop who provided useful feedback on the manuscript.

Funding Open access funding provided by University of Gothenburg. This study was supported by Grant 2017:00873 from The Swedish Research Council for Health, Working Life and Welfare (FORTE).

Data availability Replication materials are available at: https://doi.org/10.7910/DVN/XFRT7E. The full data from the Swedish National Election Study are available from the Swedish National Data Service (SND) (www.snd.gu.se) with permission. The data sources used in this paper are (Särlvik, 1960, 1964, 1970; Petersson \& Särlvik, 1973; Petersson, 1976; Holmberg, 1979, 1982; Holmberg \& Gilljam, 1985, 1988, 1991, 1994; Holmberg, 1998; Holmberg \& Oscarsson, 2002, 2006, 2010). Restrictions apply to the availability of the full datasets. The data on implemented policies can be found in the replication materials.

Open Access This article is licensed under a Creative Commons Attribution 4.0 International License, which permits use, sharing, adaptation, distribution and reproduction in any medium or format, as long as you give appropriate credit to the original author(s) and the source, provide a link to the Creative Commons licence, and indicate if changes were made. The images or other third party material in this article are included in the article's Creative Commons licence, unless indicated otherwise in a credit line to the material. If material is not included in the article's Creative Commons licence and your intended use is not permitted by statutory regulation or exceeds the permitted use, you will need to obtain permission directly from the copyright holder. To view a copy of this licence, visit http://creativecommons.org/licen ses/by/4.0/. 


\section{References}

Achen, C. H., \& Bartels, L. M. (2016). Democracy for realists: Why elections do not produce responsive government. Princeton: Princeton University Press.

Albright, J. J. (2010). The multidimensional nature of party competition. Party Politics, 16(6), 699-719.

Bolsen, T., Druckman, J. N., \& Cook, F. L. (2014). The influence of Partisan motivated reasoning on public opinion. Political Behavior, 36(2), 235-262.

Brody, R. A., \& Page, B. I. (1972). Comment: The assessment of policy voting. American Political Science Review, 66(2), 450-458.

Burstein, P. (2003). The impact of public opinion on public policy: A review and an agenda. Political Research Quarterly, 56(1), 29-40.

Campbell, A., Converse, P., Miller, W., \& Stokes, D. (1960). The American voter. New York: Wiley.

Carpini, M. X. D., \& Keeter, S. (1996). What Americans know about politics and why it matters. New Haven: Yale University Press.

Converse, P. E. (1964). The nature of belief systems in mass publics. In E. David (Ed.), Ideology and discontent (pp. 206-261). Apter: Free Press of Glencoe.

Dahl, R. A. (1989). Democracy and its critics. New Haven: Yale University Press.

Dalton, R. J. (2017). Party representation across multiple issue dimensions. Party Politics, 23(6), 609-622.

Dassonneville, R., Feitosa, F., Hooghe, M., \& Oser, J. (2020). Policy responsiveness to all citizens or only to voters? A longitudinal analysis of policy responsiveness in OECD countries. European Journal of Political Research, https://doi.org/10.1111/1475-6765.12417.

Downs, A. (1957). An economic theory of democracy. New York: Harper.

Druckman, J. N., Peterson, E., \& Slothuus, R. (2013). How elite Partisan polarization affects public opinion formation. American Political Science Review, 107(01), 57-79.

Druckman, J. N., \& Jacobs, L. R. (2006). Lumpers and splitters: The public opinion information that politicians collect and use. International Journal of Public Opinion Quarterly, 70(4), 453-476.

Erikson, R. S., MacKuen, M. B., \& Stimson, J. A. (2002). The macro polity. New York: Cambridge University Press.

Finkel, S. E. (1995). Causal analysis with panel data. Thousand Oaks, CA: Sage Publications.

Gelman, A., \& King, G. (1993). Why are American Presidential election campaign polls so variable when votes are so predictable? British Journal of Political Science, 23(4), 409-451.

Gilens, M. (2012). Affluence and influence: Economic inequality and political power in America. Princeton, NJ: Princeton University Press; Russell Sage Foundation.

Griffin, J. D., \& Newman, B. (2005). Are voters better represented? The Journal of Politics, 67(4), 1206-1227.

Holbrook, T. M. (1994). Campaigns, national conditions, and U.S. Presidential Elections. American Journal of Political Science, 4(38), 973-998.

Holmberg, S. (1979). The Swedish national election study 1979. University of Gothenburg, https://doi. org/10.5878/002509.

Holmberg, S. (1982). The Swedish national election study 1982. University of Gothenburg and Statistics Sweden, https://doi.org/10.5878/002510.

Holmberg, Sören. (1994). Party identification compared across the Atlantic. In Elections at Home and Abroad: Essays in Honor of Warren E. Miller, ed. M. Kent Jennings and Thomas E. Mann. Ann Arbor: The University of Michigan Press (pp. 93-121).

Holmberg, Sören. (1998). The Swedish National Election Study 1998. University of Gothenburg and Statistics Sweden. https://doi.org/10.5878/002515.

Holmberg, Sören., \& Oscarsson, Henrik Ekengren. (2002). The Swedish National Election Study 2002. University of Gothenburg and Statistics Sweden. https://doi.org/10.5878/002526.

Holmberg, Sären., \& Oscarsson, Henrik Ekengren. (2006). The Swedish National Election Study 2006. University of Gothenburg and Statistics Sweden. https://doi.org/10.5878/002526.

Holmberg, Sören., \& Oscarsson, H.E. (2010). The Swedish National Election Study 2010. University of Gothenburg and Statistics Sweden. https://doi.org/10.5878/002905.

Holmberg, S. \& Gilljam, M. (1985). The Swedish National Election Study 1985. University of Gothenburg and Statistics Sweden. https://doi.org/10.5878/002511.

Holmberg, S. \& Gilljam, M. (1988). The Swedish National Election Study 1988. University of Gothenburg and Statistics Sweden. https://doi.org/10.5878/002512. 
Holmberg, S. \& Gilljam, M. (1991). The Swedish National Election Study 1991. University of Gothenburg and Statistics Sweden. https://doi.org/10.5878/002513.

Holmberg, S. \& Gilljam, M. (1994). The Swedish National Election Study 1994. University of Gothenburg. https://doi.org/10.5878/002514.

Lax, J. R., \& Phillips, J. H. (2009). Gay rights in the states: Public opinion and policy responsiveness. American Political Science Review, 103(3), 367-386.

Lax, J. R., \& Phillips, J. H. (2012). The democratic deficit in the states. American Journal of Political Science, 56(1), 148-166.

Lazarsfeld, P. F., Berelson, B., \& Gaudet, H. (1968). The people's choice: How the voter makes up his mind in a presidential campaign. New York: Columbia University Press.

Leeper, T. J., \& Slothuus, R. (2014). Political parties, motivated reasoning, and public opinion formation. Political Psychology, 35(S1), 129-156.

Lenz, G. (2012). Follow the leader? How voters respond to politicians' policies and performance. Chicago: The University of Chicago Press.

Lodge, M., \& Taber, C. S. (2013). The rationalizing voter. Cambridge: Cambridge University Press.

Lupu, N. (2016). Party brands in crisis: Partisanship, brand dilution, and the breakdown of political parties in Latin America. New York: Cambridge University Press.

Manin, B., Przeworski, A., \& Stokes, S. C. (1999). Elections and representation. In A. Przeworski, S. C. Stokes, \& B. Manin (Eds.), Democracy accountability and representation (pp. 29-54). Cambridge: Cambridge University Press.

Miller, W. E., \& Stokes, D. E. (1963). Constituency influence in Congress. The American Political Science Review, 57(1), 45-56.

Miller, W.E., \& Shanks, J.M. (1996). “The New American Voter.”.

Monroe, A. D. (1979). Consistency between public preferences and national policy decisions. American Politics Quarterly, 7(1), 3-19.

Mullinix, K. J. (2016). Partisanship and preference formation: Competing motivations, elite polarization, and issue importance. Political Behavior, 38(2), 383-411.

Page, B. I., \& Shapiro, R. Y. (1983). Effects of public opinion on policy. American Political Science Review, 77(1), 175-190.

Persson, M. Forthcoming $a$. "From Opinions to Policies: Examining Links Between Citizens, Representatives, and Policy Change." Paper under review .

Persson, M. Forthcoming $b$. What explains unequal responsiveness? Investigating the role of institutional agenda setting, costly policies, and status quo bias. Paper under review .

Petersson, O. (1976). Swedish election study 1976. University of Gothenburg and Statistics Sweden. https://doi.org/10.5878/002505.

Petersson, O., \& Särlvik, B. (1973). The Swedish National Election Study 1973. University of Gothenburg and Statistics Sweden. https://doi.org/10.5878/002503.

Petry, F., \& Mendelsohn, M. (2004). Public opinion and policy making in Canada 1994-2001. Canadian Journal of Political Science, 37(3), 505-529.

Powell, G. B. (2000). Elections as instruments of democracy: Majoritarian and proportional visions. New Haven: Yale University Press.

Schakel, W. (2019). Unequal policy responsiveness in the Netherlands. Socio-Economic Review.

Soroka, S. N., \& Wlezien, C. (2010). Degrees of democracy: Politics, public opinion, and policy. Cambrige: Cambridge University Press.

Stimson, J. A., MacKuen, M. B., \& Erikson, R. S. (1995). Dynamic representation. American Political Science Review, 89(3), 543-565.

Särlvik, B. (1960). The Swedish National Election Study 1960. University of Gothenburg and Statistics Sweden. https://doi.org/10.5878/001126.

Särlvik, B. (1964). The Swedish National Election Study 1964. University of Gothenburg and Statistics Sweden. https://doi.org/10.5878/002504.

Särlvik, B. (1970). The Swedish National Election Study 1970. University of Gothenburg and Statistics Sweden. https://doi.org/10.5878/002508.

Tesler, M. (2015). Priming predispositions and changing policy positions: An account of when mass opinion is primed or changed. American Journal of Political Science, 59(4), 806-824.

Thomassen, J. (1976). Party identification as a cross-national concept: Its meaning in the Netherlands. In I. Budge, I. Crewe, \& D. Farlie (Eds.), Party Identification and Beyond (pp. 263-266). New York: Wiley. 
Tsebelis, G. (1995). Decision making in political systems: Veto players in Presidentialism, Parliamentarism, Multicameralism and Multipartyism. British Journal of Political Science, 25(3), 289-325.

Publisher's Note Springer Nature remains neutral with regard to jurisdictional claims in published maps and institutional affiliations. 